\title{
Exclusionary and inclusionary tendencies: An African relook at Paul's use of religious texts in Romans 9:26-29
}

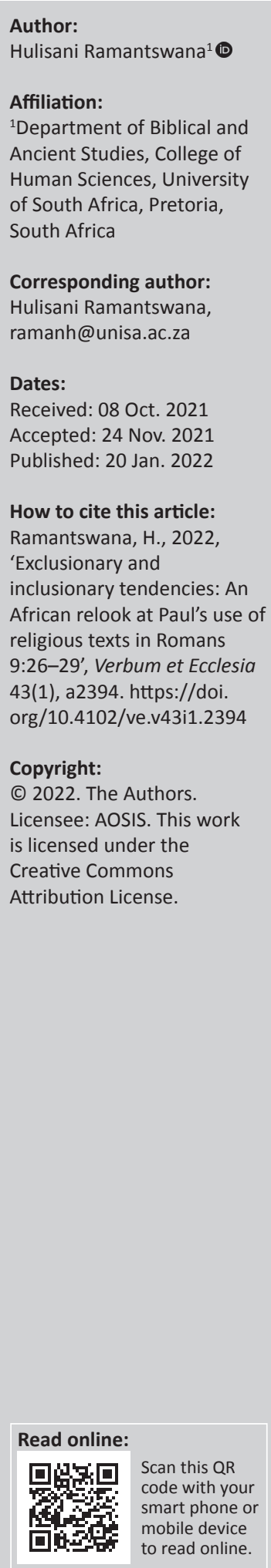

This article considers Paul's use of Scripture in Romans 9:26-29 in dealing with exclusionary and inclusionary tendencies in view of the Jews-Gentiles dilemma. In his use of Scripture, Paul uses the concept of 'seed' as a link through which he draws various texts in developing his argument as to who is included or excluded within Israel. While it is crucial to observe how Paul utilises Scripture and exegetical traditions in developing his argument, it is argued that the Jews-Gentiles dilemma cannot be solved simply by paying attention to the biblical texts as the voices of the Gentile others also need to be considered.

Intradisciplinary and/or interdisciplinary implications: This article is an intersection of Second Temple interpretation and contextual reading of texts, thereby pointing to the importance of readers' social location in reading of the biblical texts.

Keywords: seed; exclusion; inclusion; Romans; scripture; traditions; African context.

\section{Introduction}

During European colonialism, racism and ethnicity were the key pillars that governed the relationship between Europeans and the rest of the world's populations. The European colonisers considered themselves racially superior and the centre of human history, with the rest as marginalised. In the colonial system, the racial hierarchies implied that the superior had the right to land and resources. The colonial policies of exclusion and discrimination operated on racial hierarchy. Values such as freedom, human rights, inclusion, equality, etc., did not apply indiscriminately to everyone within the colonial system (Mahmud 1999:1219-1246). Unfortunately, the colonial dynamics of exclusion have not evaporated with the demise of colonialism proper - they continue to shape our lived experiences in the African context. The global pandemic, COVID-19, has exposed the structural and discriminatory global arrangements in which the privileged countries have more rights to life than others. ${ }^{1}$ As Büyüm et al. (2020) observed:

This reality shows that the current global health ecosystem is ill equipped to address structural violence as a determinant of health, and the system itself upholds the supremacy of the white saviour. (pp. 1-4)

In this article, I approach Romans 9:26-29, cognisant of the damnation and exclusions of the African people as a result of colonial structures.

In reading Romans 9:6-26, I will concentrate on Paul's use of the Old Testament, focusing on the concept of 'seed' in his address of the Jews-Gentiles dilemma - the issue of who is included or excluded within the concept of Israel. ${ }^{2}$ Paul's letter to the Romans abounds with Old Testament quotations and allusions. ${ }^{3}$ Scholars have observed that Paul primarily used biblical quotations when confronting the Jews-Gentiles dilemma. However, simply considering how Paul uses the Old Testament and/or exegetical traditions in addressing the dilemma does not entirely resolve the dilemma. The predicament over the Jews-Gentiles relationship cannot be settled simply by paying attention to the biblical texts, that is, the Jewish voices; the Gentiles, as the other, also have a voice that needs to be taken into consideration.

1.The exclusionary tendencies are showing signs with what has been deemed Vaccine Nationalism - the tendency of the rich countries to prioritise themselves for their own protection.

2.Harnack (1928) argued that Paul used Scripture only when confronting Jewish opposition.

3.From his 13 letters, Paul quotes and alludes to the Old Testament 89 times, 59 of which occurs in the letter to the Romans (Hays 1989:34). 
Reading the Romans with the Gentiles as the pivot entails a focus in front of the text - on the reader(s)/hearer(s), whose voice(s) is/are not heard in the text. In this article, my social location, a/an (South) African whose descent is among the Vhavenda people, as a reader informs my reading of the biblical text. ${ }^{4}$ In the African context, social location as a hermeneutical device cannot be dissociated from the dynamics of colonialism and Christianisation, which inferiorised and sought to desecrate our African identities, cultures and histories through the imposition of colonial identities, cultures and religion(s) (see also Ramantswana 2016:178-203). In terms of biblical religious body politics, therefore, I read as a Gentile. In reading Romans, Paul's views on the Jews-Gentile dilemma cannot be considered settled unless the voices of the Gentile others are heard. However, there is no rejoinder from the implied readers or intended readers of Romans at our disposal to engage with. As a Gentile other, who can read the text and offer his response, I engage in a dialogic encounter with the text to 're-

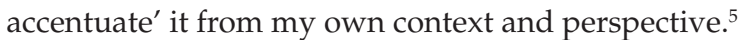

\section{Inclusion or exclusion of the alien/ gentile in scripture and second temple period}

Including or excluding the alien/stranger/nation/Gentile/ convert into Israel or Jewish identity features prominently in biblical and extra biblical texts. The matter likely gained importance during the post-exilic period to deal with the challenges faced within the province of Yehud when the golah community returned from Babylon. Some scholars highlight the multiplicity of voices on the inclusion or exclusion of the Gentiles within the Hebrew Bible/Old Testament. Olyan (2000), in his book Rites and Rank: Hierarchy in Biblical Representations, argued that ancient Israel construed her identity in terms of binary oppositions: Israel-Gentile, Israelalien, with the Gentile or the alien as the 'other' (Olyan 2000). The Israelite identity conferred upon one certain privileges, rights and duties which the other or the foreigner did not have based on the principle of exclusion. Thus, the binary opposition as reflected in the cultic context mirrored a hierarchy in Israel's society as the practices within the cultic context served to 'generate unequal social relations by limiting access to particular ritual space, actions, and items that are associated with high status, prestige, and honor' (Olyan 2000:4). Olyan also noted that the biblical texts tend to suggest different ways of overcoming the exclusion: Firstly, some texts (Holiness Code [Lv 17-26], Lv 17:8-15; 18:26-29; 19:33-34; 22:17-18; 24:10-22; 25:47-55, Is 56:3-7, Ezk 47:2223) suggest full incorporation into Israelite identity. Secondly, other texts (e.g. Ex 12:43-49) suggest the idea that males were fully incorporated through circumcision. Thirdly, some

\footnotetext{
4.Social location in this sense is not just a matter of place; it also includes a variety of factors such as culture, religion, traditions, history, socio-politico-economic issues 2007:42-58; Segovia 1995:1-17)
}

5.1 am indebted here to Bakhtin's (1981) notion re-accentuation of the text by which he refers to the readers role in activating the meaning potential of the text in dialogic encounter, which is inevitable and an organic development of the potential already embedded in the text.
Deuteronomistic texts (Dt 15:16-17, Jos 9, Jdg 1:28) suggest incorporation through subordination to an Israelite. Fourth, there are texts (Ezr-Neh, Ezr 9:1-2, Neh 9:1-2) which favour exclusion altogether. However, it should be noted that the dilemma of Jews-Gentiles is a double-edged sword cutting both ways. It is not only Gentiles who can be included in Israel, but Israelites can also be included in Gentiles. The biblical texts tend to project two ways in which Israelites can be included in the Gentiles: (1) through moral impurity following the practices of Gentiles (Lv 18) and (2) through conquest and assimilation considering the conquest of the Northern Kingdom of Israel by the Assyrians.

While Olyan emphasised the modes of overcoming exclusion of aliens from Israel's identity, Hayes (2002), in her book Gentile Impurities and Jewish Identities, argued that the exclusion of Gentiles was based on three modes of identity:

- Ritual impurity: For Hayes, in contrast to scholars such as Alon (1977:146-189) and Olyan (2000), who argued that Gentiles were considered to be intrinsically impure, she considered it to be a contingent measure with a covenantal purpose (see Ex 19:5-6, Dt 7:6-8). Gentiles were excluded from the demands of the ritual purity laws (Lv 12-15). Furthermore, they could be partially or entirely incorporated into Israelite society as resident aliens (ger), some of the resident aliens retained their ethnic identity although incorporated within Israel (Rahabites [Jos 6:25, Jr 35], ${ }^{6}$ Kennizites represented by Caleb [Jos 14] and the Kenites [Jud 1:16]; Gibeonites [Jos 9]).

- Moral impurity: In the Holiness Code (Lv 18-26), the Gentiles are associated with moral impurities such as sexual immorality in various forms, idolatry and child sacrifice. The immoral actions are considered to defile the land. The Canaanites loss of the land is pinned on their moral impurity: 'Do not defile yourselves in these ways, because this is how the nations that I am going to drive out before you became defiled' (Lv 18:24, New International Version [NIV]). The Gentiles' moral impurities also provided the rationale for the ban on intermarriage in some texts (Dt 20:18; 7:2b-4, cf. Ex 34:15-16, Lv 18:27-28; $\mathrm{Nm}$ 33:50-56). Thus, in these texts, the intimate contact with the Gentiles poses the threat of Israelites being drawn to idolatry and immoral behaviour (Epstein 1942:158).

- Genealogical impurity: The post-exilic text of EzraNehemiah, as scholars observe, introduces a complete restriction on intermarriage, which in a way extends an ideology that is also present in the Pentateuch. For Epstein (1942:162), the motive for the restriction was to preserve the purity of blood of the holy seed, which he considers to be based on racial ideology (see also, Olyan 2000:82-83). For Hayes, the prohibition of intermarriage in EzraNehemiah has the following effects: Firstly, it universalises the prohibition on intermarriage by not limiting simply to

6. Hayes and others tend to view the story of Rahab [or Rehab] in Joshua 7 as an aetology for the Rechabites, and therefore, view Rahab as an eponymous ancestor of the Rechabites (Jos 6:25, 1 Chr 4:14). Considering the difference in the spelling of of the Rechabites (Jos 6:25, 1 Chr 4:14). Considering the difference in the spelling of
the names רחב רכת the Nolan suggests that the change was likely because of pronunciation (Nolan 1982:102-107). 
the high priests or priest but extending it to all Israel. Secondly, the prohibition extends to children of mixed marriages as well - the children from a mixed union are considered profane. Thirdly, the prohibition encompasses both genders (male and female); no one is exempt. Thus, in the Ezra-Nehemiah ideology, the 'holy seed' can only come out when both parents are Israelites and not from a mixed relationship (Hayes 2002:32-34). ${ }^{7}$ For Hayes, binaries such as circumcised-uncircumcised and morally pure-morally impure were overcome through ritual purification and moral reformation. However, for EzraNehemiah, the generational impurity that formed the basis of their ideology is irremediable, applying to both males and females, and it is transgenerational (Hayes 2002:33).

The preservation of holy blood in Ezra-Nehemiah was not an innocent theological concept. It served the interests of the golah-community at the expense of the am haaretz. As Venter noted, 'Intermarriage to women outside the group threatened this exclusive body of returned exiles'. The ban on intermarriage implied that am haaretz priests who would have been in service in Jerusalem were replaced by the returned priests (see Ezr 2:61-62). Furthermore, the sending away of the foreign women and their children as projected in Ezr 10:3-4 was more than just an attempt to remedy the situation of a holy seed defiled; it was a way of excluding others from the land and its resources using the Torah as a symbol for Jewish identity and practice. ${ }^{8}$ Considering the list provided in Ezra of those willing to subject themselves to the process, one is left to wonder how many had to lose the family inheritance and properties because of the choice to preserve their families. De Villiers noted, the concept of holy seed became "a powerful metaphor for "Israel" that draws almost impenetrable boundaries, leaving no possibility for anyone to enter the community' (De Villiers 2019:1-7). In so doing, Jewish identity was not merely characterised by religious aspects such as beliefs, customs and rituals; it also embraced politics - an organisation of an ethnos politically. Therefore, the question of Jewish identity continued to arise under different circumstances focused on ethnic exclusivity of Jews from other nations, ${ }^{9}$ but also on internal contentions among the Jews on who embodies 'true' Jewish identity.

In the 2nd century BCE, under the shadow of the Greek empire and its Hellenising project, the question of Jewish identity on the one hand would again become an issue considering Antiochus IV Ephiphanes's attempt to enforce

\footnotetext{
7.Scholars consider the application of concept of "holy seed" to Israel's identity to be an invention of the post-exilic priest, who sought to create strict boundary between Israel and other nations (see Conczorowski \& Frevel 2011:81-108; Pakkala 2011:7888; Southwood 2014:102-131).
}

8.Watts $(2005: 401-417,412)$ noted that in Ezra-Nehemiah, the Torah was utilised not simply to regulate ritual and temple matters, but also to regulate the issue of intermarriage and separation from people other nations (Ezr 9:11-12, Neh 10).

9.The Ezra-Nehemiah measures of a complete ban on foreigners, prohibition of intermarriage, and expulsion of children born of foreign women, while may have served the Ezra-Nehemiah's agenda, they were not accepted by all. As Hayes noted, there are those like Philo, Josephus, Theodotus, and Testament of Levie who there are those like Philo, Josephus, Theodotus, and Testament of Levie who
continued to accept the concept of intermarriage with foreign women (Hayes 2002:73-81)
Greek customs (1 Macc 1:13-14) and desecration of the temple (1 Macc 1:21-23) and on the other were his banning of Jewish customs such as circumcision, holding the Sabbath, Jewish rituals, possessing of Jewish laws (1 Macc 1:44-50) and forcing the Jews to eat pork (2 Macc 6-7). Under the circumstances, the author(s) of 1 and 2 Maccabees bemoaned that some from Israel were swayed:
... Many even from Israel gladly adopted his religion; they sacrificed to idols and profaned the sabbath ... Many of the people, everyone who forsook the law, joined them, and they did evil in the land; they drove Israel into hiding in every place of refuge they had. (1 Macc 1:43, 52)

For the author(s) of 1 Maccabees, the Israelites who abandoned their custom, rituals and laws and subjected themselves to foreign customs were considered 'renegades/lawless/illegal/

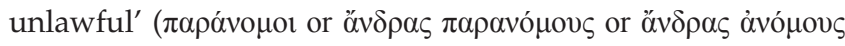
or oi ớvouor (1 Macc 1:11; 34; 2:44; 9:34, 69; 10:61; 11:21; 11:25;

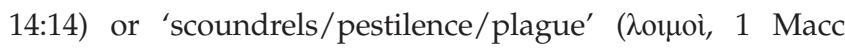

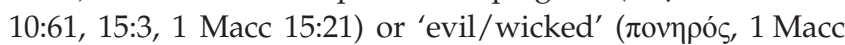
14:14) or sinners ( $\dot{\alpha} \mu \alpha \rho \tau \lambda \lambda_{\text {ó }}, 1$ Macc 2:44). Thus, in the Maccabean ideology, the Jews who subsumed themselves to foreign customs by giving up their practices were supposed to be purged as they were considered to be absorbed by the Gentile world (see 1 Macc 14:14). In a sense by abandonment of common customs, rituals and the laws, a Jewish person by descent was socially removed from Israel's collective identity (Sanders 2008:11-23, 228-232). Thus, those who did not abandon their customs, rituals and laws and were prepared to die and to join the Hasmonean movement would have been considered the true embodiment of Israel (1 Macc 1:52-64). ${ }^{10}$ The resistance of foreign customs at all costs was not a position held by all - other Jews likely became Hellenized while still maintaining certain Jewish customs and also adopting the Greek language considering the policy of Jason, the high priest, pace the Hasmonean policy. Others, however, would have become completely Hellenized through complete disassociation with Jewish customs, rituals and laws. These positions likely prevailed even under the Roman Empire.

For groups such as the Qumran community and the circle within which the Book of Jubilees originated, they followed Ezra-Nehemiah's ideology of genealogical purity (Jubilees $16: 17-18$; 22:16-22; 30; 4QMMT), However, this was intertwined with the claim of the group as true embodiment of Israel. Those in the Jubilee's circle were extremists advocating for a complete ban on intermarriage - the consequence of which was death. They also objected to general conversion by undergoing circumcision to become part of the Israelite community (Jub 30:9) in contrast to those in circle of the Testament of Levi and Theodotus, who supported marriage of Jews to Gentile converts (Hayes 2002:77-78; See also Kugel 1990:1-34). The Qumran community regarded itself as the faithful remnant, the 'true Israel', living in the eschaton (CD 1.4-7 3:5, 12-15; 8:17-18; 1

10.1n 1 Maccabees $1.53-64$ the concept lsrael is used to refer to a people and to place. Thus, there are those in Israel, that is in the land, who abandoned their customs, rituals, and laws, while others did not. It is particularly those who did not customs, rituals, and laws, while others did not. It is particularly those who did not
abandon their customs, rituals, and laws, who are specifically referred to as 'Israel' (1 Macc 1:53, 58) 
QpHab 9:5-11; 12:5-13; 1 QH 6:7f.; 1 QM 13:8; 14:8f.; 4 QIsa Frag 2-6 col 2.4; 4 QIsa ${ }^{\mathrm{c}}$ Frags 4-6 col. 2.10). To maintain their purity, the Qumran community as those in the circle of Jubilees required genealogical purity through a ban on intermarriage with the gentiles. Members of the community were in accordance with the Rules of the Congregation supposed to be 'native-born Israelites' (1 QSa 1:1, 6). Nevertheless, the Qumran community held to a view of graded Israel in relation to broader Israelite community and internally with regard to Gentile converts. The Gentiles converts (gerim) into the Israel and/or the Qumran community, while could be accepted into Israel; they however, could not necessarily attain a higher-level Israel identity. In the Damascus tradition, a convert (ger) could be accepted into the community as a full member whereas of the Qumran community. In contrast, in the Serekh tradition, the Gentile coverts while could be embraced in Israel they still retained their Gentile ethnicity (Palmer 2018).

During the Second Temple period, there was a degree of tension between Israelites/Jews' attempt to preserve their identity and their relation and mission towards other nations. Such tension was in some sense part of and a continuation of the multiple voices within the Hebrew Bible/Old Testament regarding Israel's relation with other nations - a relationship in which Gentiles can become Israel/Jews and conversely Israel/Jews can become Gentiles (1 Macc 1:15). The Gentiles becoming Jews is portrayed in numerous ways during the Second Temple texts, and therefore, a few examples will suffice: Gentiles becoming Jews out of fear or voluntary association (LXX Esther 8:17; Judith 14:10; Against Apion 2.39, 283; 2 Macc 9:17; Bel and the Dragon 28), forceful subjection of Gentiles (Ant. 13:258-258; 13:397; Bell. 1:63; Strabo, Geogr. 16.2.34), Gentiles converts to marry Jewish women (Jewish Antiquities 20.7.1; 139; 20.7.3; 145-146). ${ }^{11}$ While Gentiles could become Jews, according to Bird (2010), it did not necessarily imply that there was an intentional Jewish effort aimed at converting Gentiles to Jews. According to Bird, the Jewish efforts to convert Gentiles likely varied from one group to another, While there were those who were more concerned with genealogical purity of Jews, others would have an open mindset to allow Gentiles to become Jews, and yet others would have made efforts to go all out to convert Gentiles (Mt 23:15). The Jesus movement also had to deal with this tension. As Wassen (2016:18) noted, 'Jewish identity is not a stable category, but changes from the viewpoint of different groups'. Therefore, in considering letter of Romans, it is essential to consider how Paul deals with the Jews-Gentiles dilemma.

In Romans, Paul addresses the Jews-Gentiles dilemma in great detail in light of the Scriptures among other issues. ${ }^{12}$ The dilemma, as Käsemann (1980:262) argued, needed urgent attention as the notion of 'Israel' was contested. In addressing Jews-Gentiles dilemma, Paul does so from a 11.For more on Gentiles becoming Jews (see Cohen 1989:13-33). 12.It should come as no surprise that Paul addresses this issue as his letters were probably the first to be written to this community of believers called $\varepsilon$ $\kappa \kappa \lambda \eta \sigma i ́$ (church) distinct from the synagogue.
post-Messianic stance - the Messiah has already been revealed in the person of Jesus Christ (see Bruce 1983:77-98, 97). Paul viewed his duty as proclaiming Jesus Christ and

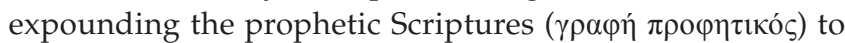
all nations (see $\mathrm{Rm} 1: 1-5 ; 16: 25-26$ ). However, Paul's ministry as portrayed in the Book of Acts was initially focused on the Jews and subsequently shifted to the Gentiles (13:46-48). In Paul's view, in order to win people to Christ, it required some level of purposeful association with Jews and Gentiles - the weak and the strong ( $\mathrm{Rm}$ 15:1, 1 Cor $1: 27 ; 9: 19-27)$.

In the letter to the Galatians, Paul argued that those who are in Christ are Abraham's seed (see Gl 3:1-29; esp. vv. 9, 16, 26-29). In such a view, Paul regarded Abraham's faith as an archetype for Gentiles who are justified by faith. He argued that the promises made to Abraham were made for him and his seed. In Galatians 3:16, Paul draws a sharp distinction concerning the seed by pointing out that in the promise, God did not say $\tau \tilde{\omega} \sigma \pi \dot{\varepsilon} \rho \mu \alpha \tau o l$ ('to seeds') as of many, but as of one $\tau \tilde{\omega}$ $\sigma \pi \varepsilon \dot{\varepsilon} \mu \alpha \tau i$ бov ('to your seed'), which he takes to mean Christ, the only righteous remnant. In Hebrew, the word translated as 'seed' is the singular זרט which is continually used collectively in the Hebrew Scriptures to denote one's descendants (see Ellis 1957:71). As Enns (2005:137-138) pointed out, 'Paul seizes the grammatical ambiguity of the word, in good Second Temple fashion, and uses it to make a profound point about Christ and his people'. In Roman 9:6-29, Paul addresses the Jews-Gentiles dilemma by evoking the concept of 'seed' by taking as the primary text of appeal as Genesis 21:12, which generates themes and propositions to draw other secondary texts (or quotations) including Isaiah 1:9.

While it is essential to highlight that Paul was writing from the post-Messianic stance, we should not overlook that Paul was a Jew, not a Gentile. However, in Acts, Paul is projected to embrace a Gentile identity as a Roman citizen (Ac 16:3738 ; 22:25-29; 23:27) - an identity not found in the Pauline letters as a way of Paul's self-representation. ${ }^{13}$ While Paul's hybrid identity cannot be likely dismissed, Paul's argument on the Jews-Gentile relationship is Jewish. Paul's voice should not be read or understood as a voice representing the Gentile perspective on the matter. For the most part, what we have in the New Testament are the Jewish-Christian perspectives on the relationship, which cannot be regarded as applicable for everyone everywhere. In my view, in the encounter with the Gentile others, the discussion can find a relative resolution.

\section{Paul's use of scripture in Romans 9:26-29: Developing the argument through use of multiple scriptural texts}

In his letter to the Roman, Paul develops the intensity of the Jews-Gentiles dilemma in chs. 3 and 4 by making use of

13.Some scholars argue that that Paul's identity as a Roman citizen was a Lukan invention (see Lentz 1993; Stegemann 1987:200-229). 
diatribe style. ${ }^{14}$ The following rhetoric string of questions is observable:

- Roman 3:1 - What advantage, then, is there in being a Jew, or what value is there in circumcision?

- Roman 3:3 - What if some did not have faith? Will their lack of faith nullify God's faithfulness?

- Roman 3:9 - What shall we conclude then? Are we any better?

- Roman 3:27 - Where, then is boasting? It is excluded. On what principle? On that of observing the law?

- Roman 3:29 - Is God the God of Jews only? Is he not the God of Gentiles too?

- Roman 3:31 - Do we, then, nullify the law by this faith?

- Roman 4:1 - What then shall we say that Abraham, our father discovered in this matter?

- Roman 4:3 - What does the Scripture say?

All these rhetorical questions, which are interrelated, are a builtup to an intensive inquiry into Scripture. Like his Judaic contemporaries, Paul did not merely appeal to Scripture for proofs; the scriptures served as a 'powerful instrument of profound inquiry' (see Neusner 1989:1-6). As in Galatians, the Abraham story is foundational for Paul's argument which is grounded on Genesis 15:6, which is his primary text in Roman 4 and through which he generates themes and propositions. Hays (1989) rightly observed that the story of Abraham in ch. 4:

[I]s told as it is told (or as Paul would say, these things happened to Abraham in the order which they happened) in order that Abraham might fitly serve as the archetype for Gentile believers as well as Jewish believers. (p. 56)

In Roman 9:6-29, Paul takes as his primary text of appeal Genesis 21:12 linked to the argument in ch. 4 by means of a keyword $\sigma \pi \varepsilon \dot{\rho} \mu \alpha$ ('seed') which is repeated three times in 4:13, 16,18 . However, for Paul the concept of Abraham's seed goes hand in hand with the promise (i் $\pi \alpha \gamma \varepsilon \lambda \mathrm{l}$ ). In Roman 4:16, Paul ties the concept of seed and promise as follows:

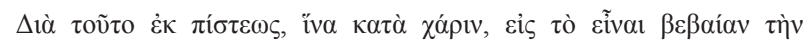

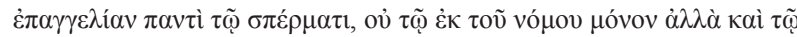

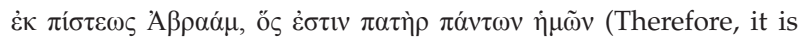
through faith, that in accordance to grace, so that the promise might be guaranteed for all seeds, not only for those who are of the law but also those who are of faith of Abraham, who is the father of us all).

The promise in the context of ch. 4 is that of being 'heirs of the world' (see v. 13) and that promise is for 'all' (v. 16) by which is implied both Jews (those who are of the law) and Gentiles (those who are of the faith of Abraham). However, the promise presupposes faith in both Jews and Gentiles. By making Genesis 21:12 to serve as a primary text, Paul uses a basic exegetical pattern which is exemplified rabbinic midrash. Kugel made the following observation concerning rabbinic midrash: 'Most of the narrative expansions found

14. Diatribe is "philosophical conversation - a technique evolved by the Cynic and Stoic schools for popularising philosophical and ethical ideas ... They [diatribes] are distinguished by a familiar and lively interchange of question and answer, ironic apostrophe and personal appeal' (Dodd 1932:148). However, some scholars deny the presence of diatribe arguing that Paul's interpretation is purely Jewish and the presence of diatribe arguing that Paul's interpretation
rabbinic (Dodd 1932; Ellis 1978:154, 219; Scroggs 1976:278). in rabbinic midrash and other early texts have as their point of departure some peculiarity in the biblical text itself' (Kugel 1990:247). As to how Genesis 21:12 function in Romans 9:6-29, I will attend to it subsequently.

Scholars' mainly regard Roman 9:6-29 as a distinct literary unity within Paul's scriptural argumentation in Roman 9-11 (Heil 2002:703-720, 704). In Roman 9-11, Paul again returns to the Jews-Gentiles dilemma after a break in chs. 5-8, wherein Paul makes an exposition of the Christ event and its implications for faith. ${ }^{15}$ Paul intensifies the Jews-Gentiles dilemma in 9:1-5 by his grief over what he says 'my brethren,

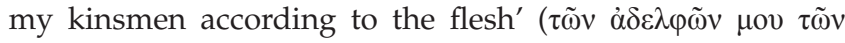

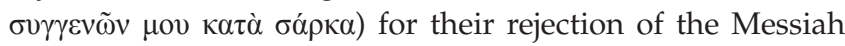
and his gospel in consideration of all the privileges which they enjoyed from God. ${ }^{16}$

In Roman 9:6-29, Paul makes an intensive utilisation of standard Jewish exegetical procedure known as gezera shawa, which means 'an inference from analogy of expressions' (Kasher 2004:547-594, 584; Longenecker 1999:100-101). Through this procedure, Paul joins various passages on the basis of particular keyword or phrase (sometimes called catchword or stitchwort). ${ }^{17}$ We have already observed that Paul's argument in Roman 9:6-29 is linked to his earlier argument in ch. 4 through the keyword $\sigma \pi \varepsilon \dot{\rho} \mu \alpha$.

The following scriptural interplay is observable in Roman 9:6-29:

vv. 6-7: Primary text: Genesis 21:12 - two keywords: $\sigma \pi \varepsilon \dot{\varepsilon} \mu \alpha$ and $\kappa \alpha \lambda \dot{\varepsilon} \omega$

v. 9: $\quad$ Supplementary text: Genesis 18:10 - quoted as

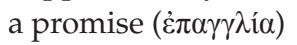

vv. 7-21: Exposition containing additional citations the keyword $\kappa \alpha \lambda \varepsilon \dot{\omega} \omega$ set the pitch for the rest of the quotations and allusions: verses $12 \mathrm{~b}(\mathrm{Gn}$ 25:23), verse 13 (Ml 1:1-2), verse 15 (Ex 33:19), verse 17 (Ex 9:16).

vv. 22-28: Further exposition - keyword $\kappa \alpha \lambda \varepsilon ́ \omega$ repeated in verse 24 to draw the next string of quotations: verse 25 (Hs 2:23); verse 26 (Hs $1: 10$ ); verse 27 (Is 10:22, 23)

v. 29: A final text alluding to the initial text with the keyword $\sigma \pi \varepsilon \dot{\rho} \mu \alpha$ and thus forming an inclusio. ${ }^{18}$

15. However, in Roman 5-8, Paul's use of Scripture is allusive and indirect with an exception of two explicit quotations from Scripture (in 7:7 and 8:36). It will be further reading concerning Paul's distribution of biblical quotations in Romans further reading concerning Paul's distribution of biblical quotations in Romans
see (Beker 1993; Harnack 1928:121-141; Longenecker 1997:1-24; Scroggs see (Beker 1993;
1976:271-298).

16.In verses $4-5$ he identifies about nine privileges which his brethren and kinsmen according to the flesh had and yet failed to recognize the Christ: (1) he calls them Israel (9:4a); (2) their adoption (9:4b); (3) glory, by which he probably means God's glory revealed to them (9:4c); (4) the covenants (9:4d); (5) they had been given the law (9:4e); (6) they had the privilege of worshiping God $(9: 4) ;(7)$ the promises were given to them $(9: 4 \mathrm{~g}) ;(8)$ to them belong the fathers $(9: 5 a) ;(9)$ they are the people from whom the Messiah came according to the flesh (9:5b)

17.This rule of interpretation is part of the seven rules of interpretation known as middoth, which are attributed to Hillel the Elder (1st century BCE) and were in wide use among the rabbis in the 1st century AD.

18. The scriptural interplay is a modification of Ellis scriptural interplay as found in Ellis (1978:155). 
In Roman 9:6-29, Paul is not merely citing texts from Scripture but rather draws them together to argue a point. The independent quotations cannot be understood in isolation as brief explanations do not always follow them. The scriptural interplay needs some explanations to get a clear picture of how Paul draws the various scriptural passages together analogically.

In light of Roman 9:1-5, wherein Paul grieves over the disbelief of his fellow brethren according to the flesh, he restates his thesis in verses 6-7:

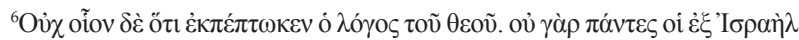

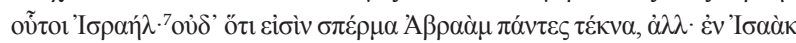

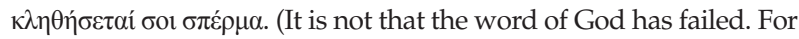
not all who are of Israel are Israel. Nor is it that all children are seed of Abraham, rather in Isaac will your seed be called.)

The question that Paul seeks to answer is: In what way has the word of God not failed? Paul clarifies by highlighting what it entails to be a seed of Abraham. ${ }^{19}$ Schreiner rightly observed that the distinguishing process within the

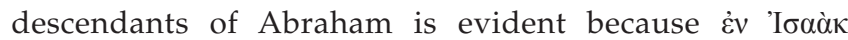
$\kappa \lambda \eta \theta \eta \dot{\sigma \varepsilon \tau \alpha i ́ ~ \sigma o l ~ \sigma \pi \varepsilon ́ p \mu \alpha ~(" i n ~ I s a a c ~ y o u r ~ s e e d ~ s h a l l ~ b e ~ c a l l e d ") ' ~}$ (Schreiner 1998:495). Thus, Paul takes this section from Genesis 21:12 as his primary text (see above, 9:7b). There are two keywords in the primary text: the word $\sigma \pi \varepsilon p \mu \alpha$, which is part of the formulation of his thesis and also part

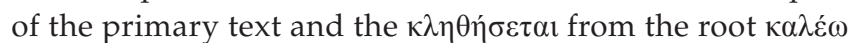
meaning 'to call'. The quotation of Genesis 21:12 is 'followed by a pesher-style commentary (i.e. a commentary that cites a text line by line and glosses each line with a brief explanation)' (Hays 1989:65). Thus, in verses 8 and 9, Paul is making use of a Midrashic form of exposition by contrast. As Borgen observed, such an exposition by contrast uses the following pattern: Exposition is given by a pattern of contrast (ov̉ ... $\dot{\alpha} \lambda \lambda \dot{\alpha}$ ) followed by a sentence introduced by 'for', $(\gamma \alpha \hat{\alpha} \rho) .{ }^{20}$ This pattern can be clearly observed in Roman 9:8-9:

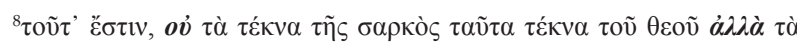

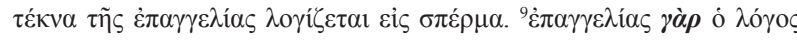

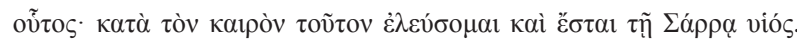
(This means, it is not the children of the flesh who are children of God but the children of the promise are reckoned for seed; for this is the word of promise: 'About this time I shall return and Sarah shall have a son'.)

19. Careful note should be taken on Paul's use of the term 'Israel': 'First, the specialized use of the term "Israel" applies only to 9:6 and should not be allowed to determine one's reading of 11:26. Second, except for 9:6, every occurrence of the term "Israel" in Roman 9-11 points specifically to a racial group - ethnic Israel ... Third, as a consequence of the first two points, there is no reason to believe that Paul as a consequence of the first two points, there is no reason to believe that Paul means in 11:26
1989:95-123).

20.This pattern is also found in Philo ('Cain rose up against Abel his brother and slew him (aútóv)' (Gn 4:8) ... It must be read in this way, 'Cain rose up and slew himself

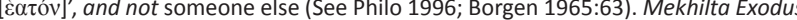
16:15 (Pattern of contrast: "Man did eat the bread of strong horses" (Ps 78, 25) Do not read (אל תקרי) "of strong horses" (אבירים), but (אלא ) "of the limbs" (אבירים) that is, bread that is absorbed by the limbs'. See also Borgen, Bread from Heaven, 63), and John 6:32-33 (e same pattern of contrast can be observed from the words of , and Jo las of Jesus as laid out in M

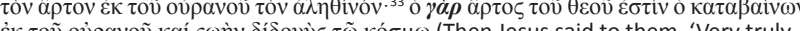

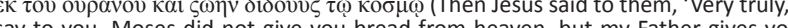
say to you, Moses did not give you bread from heaven, but my Father gives you true bread from heaven; for the bread of God is that which comes down from heaven and gives life to the world'). (See also Borgen 1965:62).

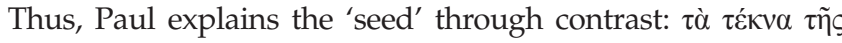

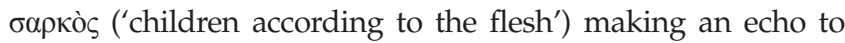
Paul's grief over the unbelieving and more clearly stated, 'they are not the children of God'. Instead, the children of غ̇ $\pi \alpha \gamma \gamma \varepsilon \lambda i{ }^{\alpha} \alpha$ ('promise') are reckoned as the seed. The concept of promise provides a link between the explanatory and the next proof-text (Rm 9:9, which quotes Gn 18:10, 14), which is specifically quoted as 'promise'. Most interestingly in Genesis Rabbah LIII: $\mathrm{I}-\mathrm{V}$, the promise made to Sarah is 'associated with the theme of the steadfastness of God's word'. ${ }^{21}$ However, with Genesis Rabbah, the primary text on the steadfastness of God's word is Genesis 21:1. The example below from Genesis Rabbah LIII: IV illustrates this theme of the steadfastness of God's word:

1. a. 'For ever, O Lord, your word stands fast in heaven' (Ps 119:89):

b. But does God's word not stand fast on earth?

c. But what you said to Abraham in heaven, 'At this season I shall return to you' (Gn 18:14) [was carried out:]

d. 'The Lord remembered Sarah as he had said and the Lord did to Sarah as he had promised' (Gn 21:1). ${ }^{22}$

Paul, by citing Genesis 18:10, 14 and connecting it with the promise, was using an established exegetical tradition to argue that God's word has not failed as the seed of Abraham is not only limited to 'the children according to the flesh', that is, by natural descent.

The verb $\kappa \alpha \lambda \varepsilon \dot{\varepsilon} \omega$ as found in the primary text, is used to provide two linkages: the seed as a matter of God's election and the Gentile believers as seed through God's calling. In the first instance, Paul directs attention to God to illustrate how God makes things work for his own purpose through this keyword. God's election of Jacob over Esau was purely God's choice. The keyword, in this case, is used to describe God himself and is not necessarily found in the quotations that are drawn. According to 9:11-12a, God's election continues or stands 'not

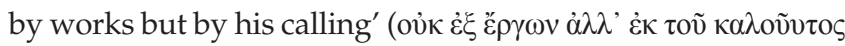
[from the verb $\kappa \alpha \lambda \dot{\varepsilon} \omega]$ ]). The two quotations, one in 9:12a and the other from v. 13 are respectively quoted from Genesis 25:23 and Malachi 1:1-2. In Roman 9:14-23, Paul defends God's sovereignty in his calling. In these verses, Paul again uses the diatribe style to argue his point. He engages in an interchange of questions and answers arguing his point from Scripture by making direct quotations (Ex 33:19 and 9:16) and drawing his metaphors of a potter which echoes several texts from the Old Testament and second temple Judaism (Is 29:16; 45:9-11, Jr

21.It should also be noted that in Jewish legends Sarah is also regarded as the only woman with whom God ever spoke (Ginzberg 1913:78, 203; Stegner 1984:37-52, 47)

22.Quoted from Genesis Rabbah: The Judaic Commentary to the Book of Genesis (Vol II, trans. Neusner 1985:245). Two other examples can be cited from Genesis Rabbah to really pound this point:

Genesis Rabbah LIII:I

1. a. 'The Lord remembered Sarah as he had said [and the Lord did to Sarah as he had promised]' (Gn 21:1):

b. This is in line with the following statement of Scripture: 'And all the trees of the field shall know that I the Lord have brought down the high tree, have exalted the low tree, have dried up the green tree, and have made the dry tree to flourish; I the Lord have spoken and done it' (Ez 17:24).

Genesis Rabbah LIII: III

2. a. 'The grass withers, the flower fades' (Is 40:8):

b. The grass of Abimelech withers and his flowers fades.

c. 'But the word of our God stands forever' (Is 40:8)

d. 'The Lord remembered Sarah as he had said and the Lord did to Sarah as he had promised' (Gn 21:1) 
18:1-6, Wis. 15:7, Sir. 33:7-13; T. Naph. 2:2, 4; 1QS 11:22; 1QH 9[1]:21; 11[3]:23-24; 12[4]:29; 19[11]:3; 20[12]:26, 32) (Schreiner 1998:515-516). In Roman 9:14 and 19, Paul uses an exegetic syllogism explicitly designed to clarify an incorrect inference from a preceding verse (Stegner 1984:37-52, 43). As Cranfield

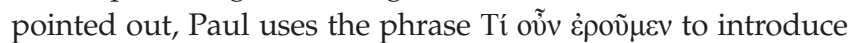
'the indication of the false presupposition', thereby 'indicating and rejecting the possible false conclusion before stating his own conclusion' (see also Rm 3:5; 6:1; 7:7) (Cranfield 1975:481f.). This form of the exegetic syllogism is also found in Mekhilta, ${ }^{23}$ making it possible that the form known and employed by Paul was developed into the syllogism that we know from Mekhilta' (Stegner 1984:43).

In the second instance, the keyword $\kappa \alpha \lambda \varepsilon^{\omega} \omega$ is repeated again in

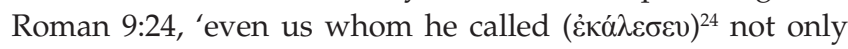
from the Jews but also from the Gentiles'. This keyword is used to draw in Hosea 2:23 and 1:10 in verses 25-26 (Stegner 1984:40). In light of Hosea 2:23, God states 'Those who were not my people I will call "my people" and her who was not

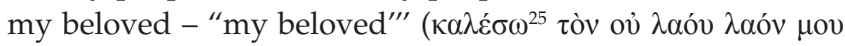

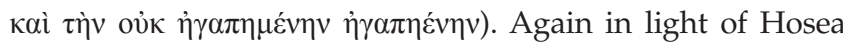
1:10, he states 'and it shall be - in the place where it was said to them, You are not My people; there they shall be called sons

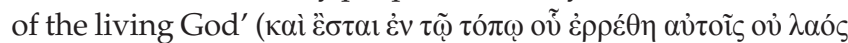

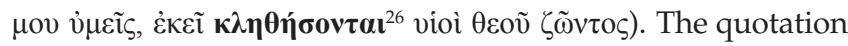
of Hosea 2:25, while it somewhat reflects the LXX, it also departs from it. According to Cosgrove, 'it looks as if Paul is denying the literal sense of (the Septuagint versions of) Hosea 2:1 and 2:25, which refer not to Gentiles but to Jews'. ${ }^{27}$ Hosea's prophecies were directed initially to the northern tribes of Israel; however, Paul sees these prophecies as fulfilled in the calling of Gentiles (Schreiner 1998:528). From this, an inference can be drawn that Gentiles are 'seed' according to the promise made to Abraham.

Considering the argument of Paul in Romans 9:6-29, genealogy is not a sufficient criterion for determining who an Israelite is. One can be an Israelite by descent (birth), yet not considered part of Israel. The criterion for determining who belongs to the 'true Israel' is unlike in Ezra-Nehemiah, wherein genealogy is the criterion for 'holy seed'. For Paul, the criterion for being excluded or included in 'true Israel' is not defined simply based on descent or genealogy but faith. This, in turn, implies

\footnotetext{
23.According to Mihaly 'this type of exegetic symbolism occurs close to 150 time in tannaitic midrash'. In these cases when a passage is introduced by the question

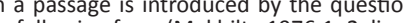
Ita 1976:1-2, lines 2 and 21).

1. The citation of the verse.

2. The formula - למה נאמר

3. Citation of another biblical verse which is not inclusive enough or form which one may draw a wrong inference which needs to be corrected - usually introduced by לפי שנאמר or its equivalent.

4. The incorrect inference drawn from the second verse (Step C) introduced by אין לי יכול or similar term.

5. The original verse which clarifies the matter and corrects the possible error introduced by ח (Mihaly 1964:103-143, 141).
}

24.Verb indicative aorist active third person singular of $\kappa \alpha \lambda \varepsilon \dot{\varepsilon} \omega$.

25.Verb indicative future active first person singular of $\kappa \alpha \lambda \dot{\varepsilon} \omega$.

26.Verb indicative future passive third person plural of $\kappa \alpha \lambda \varepsilon \dot{\varepsilon} \omega$.

27.For Cosgrove (1996:271-287, 275), Paul was playing a trick with the readers by giving the impression that God is not bound by any promises made to ethnic Israe until they reach chapter 11 . that those who have faith would be the ones who are regarded as the children of the promise, not mere Israelites by descent. This is based on Abraham's other children who were not considered children of the 'promise'. This implies that those who are Israel by descent can be excluded because they are not children of the promise. Although they are Isaac's descendants genealogically, yet they are not Israel. This is stretched further to Jacob and his twins - Esau and Jacob, which is taken as an additional indication that genealogy is not a sufficient criterion for determining 'true Israel'.

Paul's inclusion of Gentiles in Abraham's seed also stands in contrast to Jubilees 22, which sets Abraham as a separatist, who on his deathbed informed Jacob of his election as 'a righteous seed' and instructs him on the separatist ideology:

Separate thyself from the nations, and eat not with them; and do not according to their works, and become not their associate; for their works are unclean, and all their ways are a pollution and abomination and uncleanness... (Jubilees 22:16-30)

For those in the Jubilee group, Abraham blessed Jacob's seed, and therefore Jacob's seed is 'holy seed' genealogically, and no Gentile should be included therein (see Jubilees 22:24). For Jubilees, in blessing Jacob, Abraham 'adopted' Jacob as his son from Isaac (cf. Gn 48:8-24). Paul, on the other hand, also uses the language of adoption with reference to Israel, '.. the people of Israel. Theirs is the adoption as sons' (Rm 9:4, NIV); however, for him adoption is not the sole criterion for inclusion into Abraham's seed, but promise as well through the calling of those who were not God's people or God's beloved to be 'sons of the living God' (Rm 9:26).

\section{The remnant as the seed divinely preserved - The use of Isaiah 10:22, 23 and 1:9 in Romans 9:27-29}

In verses 27-29, Paul quotes two passages from Isaiah (9:27-28 [Is 10:22, 23]; 9:29 [Is 1:9]). The two questions of relevance are: firstly, how does Paul relate these two passages? Secondly, building on the coherence of 9:6-29 already established above, how does the quotation of Isaiah 1:9 fit in Paul's argument? How was Isaiah 1:9 used in its original sense?

How are the two quotations in Roman 9:28-29 related? In the first place, the two quotations are taken from the same prophet, Isaiah. This should be viewed as a conscious move by Paul to relate these two passages. This is evident in the manner that the quotations are introduced - the quotation of Isaiah 10:22, 23 is

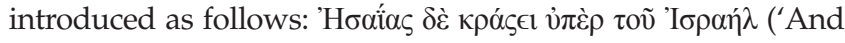
Isaiah cries out on behalf of Israel'). Commentators disagree on how the preposition $v \pi \dot{\varepsilon} \rho$ should be rendered. ${ }^{28}$ Heil argued that it should be rendered as 'on behalf of', thus taking the term 'Israel' to refer to the presently unbelieving Israel as opposed to taking it as referring to a small number of believing Jews who are now part of God's people along with believing Gentiles (Heil 2002:707). In this case, the term 'Israel' should rather be 28.Most translations translate vize as 'concerning' or 'about' thus rendering it as the equivalent of $\pi \epsilon \rho 1$. 
viewed as referring to the Jewish community at large rather than seeing it as a special usage to refer either to the believing Jews or unbelieving Jews. The main point for Paul in this instance is not on either group but on God's unfailing word (see 9:6). The quotation of Isaiah 1:9 is introduced as follows:

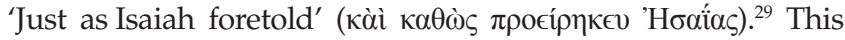
introduction does not simply set this prophecy as presently valid. Instead, it should be understood as placing Isaiah 10:22, 23 as a fulfilment of Isaiah 1:9.

In his quotation of Isaiah 10:22, 23, Paul makes alterations to the text. This citation, as Schreiner noted, is 'roughly from Isaiah 10:22-23 LXX and perhaps also with Isaiah 28:22 LXX (cf. also Dan. 5:28 LXX)' (Schreiner 1998:528). According to Ellis, 'in the use of the Old Testament by the New, implicit midrash appears in double entendre, in interpretive alterations of Old Testament citations and in more elaborate forms' (Ellis 1978:152). This quotation is an example of an interpretive alteration of the Old Testament. Longenecker called such quotations as 'ad hoc creations', which Paul probably created himself or 'stem in some manner from earlier Christian interpreters' (Longenecker 1989:97). Paul replaces 'the people of Israel' in Isaiah 10:22a with 'the number of the sons of Israel' from Hosea 2:1a. According to Heil, this is to avoid confusion with the expression 'my people' in Roman 9:25-26 (Heil 2002:711). The last section of Isaiah 10:22 is abridged to

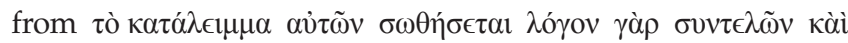

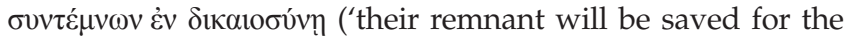

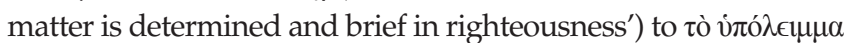
$\sigma \omega \theta \eta ் \epsilon \tau \alpha_{l}$ ('the remnant will be saved'). ${ }^{30}$ Heil persuasively argued that the simile of the sand as an expression of God's word of promise recalls the various expressions of God's promise to Abraham of innumerable descendants - as innumerable as the 'sand' of the earth or of the sea (Gn 16:13; 22:17; 28:14; 32:12 [32:13 in the LXX]) (Heil 2002:712). However, Paul is also adamant to point out that only a remnant will be saved. Heil arbitrarily reads the quotation of Isaiah 9:23 in Roman 9:28 to be referring to God's word of promise that the descendants of Israel will be as numerous as the sand of the sea as an irrevocable matter before God. The idea of a remnant should rather be understood not simply as a matter of a promise but as a comfort to God's people that he will not completely abandon them. It is this concept of remnant which provides a linkage between Roman 9:27-28 and 9:29. As already pointed out, the quotation of Isaiah 1:9 is introduced as a prophecy that foretold a remnant's survival. Paul clearly sees a connection between $\sigma \pi \varepsilon \dot{p} \mu \alpha$ ('seed') in Isaiah 1:9 and vं $\hat{\prime}^{\prime} \in 1 \mu \mu \alpha$ ('remnant') in Isaiah 10:22. Therefore, it is necessary to consider how Isaiah 1:9 is used in its original context so as to get a clear grasp of what Paul is doing with this text.

Paul quotes Isaiah. 1:9 from the Septuagint (LXX) just as he does in most of his quotations. There is a significant variation between the Hebrew text and the Septuagint, which Paul quotes. ${ }^{31}$

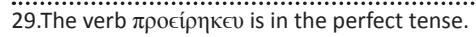

30.The choice of word also varies, the word rendered as 'remnant' is $\dot{v} \pi$ ó $\lambda \in \mu \mu \alpha$ instead of $\kappa \alpha \tau \dot{\lambda} \lambda \epsilon \iota \mu \mu \alpha$.

31.Paul as well as other New Testament writer frequently follows the Septuagint which is the Greek version of the Old Testament produced during the Hellenistic
TABLE 1: Isaiah 1:9.

\begin{tabular}{|c|c|c|}
\hline MT & & LXX \\
\hline & 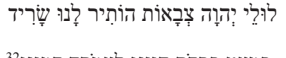 & 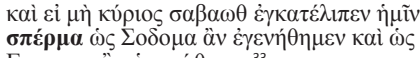 \\
\hline
\end{tabular}

The difference between the Hebrew text and the LXX is that

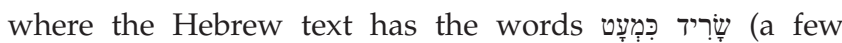
survivors), the LXX uses the word $\sigma \pi \varepsilon \varepsilon^{2} \mu \alpha$ (seed). In the LXX, the word $\sigma \pi \varepsilon \dot{\rho} \mu \alpha$ is used 28 times $^{34}$ mainly to translate the Hebrew noun זִר except in a few cases where it is used to replace other nouns (as is the case in Is 1:9) (35 $^{35}$ and in cases where it was probably added because of variant readings. ${ }^{36}$

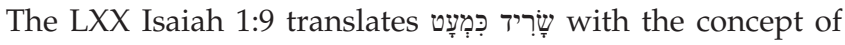
$\sigma \pi \varepsilon \dot{\rho} \mu \alpha$ instead of translating the Hebrew idiom literally. The LXX translator was either working with a variant text tradition or deliberately opted to harmonise the text as Israel

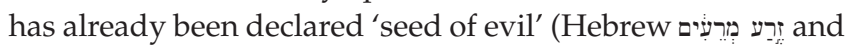

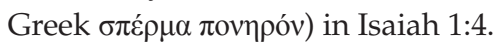

In Isaiah 1:9, the prophet Isaiah speaks on behalf of the people to show the misconception among the survivors of Israel. ${ }^{37}$ The people of Israel were contrasting their fate with that of Sodom and Gomorrah. It is true that they were not completely destroyed, as was the case with Sodom and Gomorrah. However, the contrast they were making between themselves and Sodom and Gomorrah was in terms of their survival, not their indifference. Before the eyes of Yahweh, Sodom and Gomorrah are a symbol of those who choose to oppose the purposes of God and a paradigm for devastating judgement (eds. Leland, Wilhoit \& Longman 1998:802). As a result, in Isaiah 1:10, Yahweh addresses their rulers as 'rulers of Sodom' and the people as 'people of Gomorrah' (see Is 1:10). Thus, Isaiah 1:9 and 10 are used dichotomously to expose the misconception of Israel's survivors. It can be concluded that Isaiah 1:9 in its original sense is used negatively to show the false pretension among the survivors (or the seed) of Israel.

For Paul, Isaiah 1:9 is a prophecy that foretold a remnant's survival. Furthermore, Paul's quotation of Isaiah 1:9 also serves as an inclusio to tie together Roman 9:6-29 by means of a keyword $\sigma \pi \varepsilon p \mu \alpha$ ('seed'), which is also found in verse 7 . Käsemann called this a 'backward glance at what was said about the genuine seed of Abraham in verses 7ff., and the term "seed" is reminiscent of that' (Käsemann 1980:276).

\footnotetext{
period in the process which began in 3rd century B.C. This version was widely used both in Palestine and the Diaspora during the first century A.D.
}

32.Own translation: Unless Yahweh Sebaoth had left for us a few survivors, we would have been like Sodom, we would have become like Gomorrah.

33.Own translation: And if the Lord Sebaoth had not left us a seed, we would have become like Sodom and we would have been made like Gomorrah.

34.Isaiah 1:4, 9; 14:20, 22, 30; 15:9; 17:5, 10; 23:3; 31:9; 33:2; 37:31; 41:8; 43:5; 44:3 $45: 25 ; 48: 14,19 ; 53: 10 ; 54: 3 ; 55: 10 ; 57: 3 f ; 61: 9 * 2 ; 65: 9,23 ; 66: 22$.

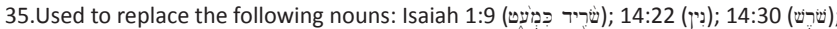
37:31 (פְר).

36.Isaiah 15:9; 17:5; 31:9.

37. Sweeney (1996:77) rightly pointed out that 'remnant' (or the survivors) imagery in Isa. 1:9 is entirely appropriate to the 701 setting. After Sennacherib had destroyed 46 Judean cities and carried over 200000 inhabitants, Jerusalem was certainly a remnant. 
The apostle Paul follows this pattern in 9:6-29, which scholars identify as an example of homiletic midrash found elsewhere in Philo, ${ }^{38}$ Rabbinic literature, ${ }^{39}$ and elsewhere in the New Testament (see Borgen 1965:46-58; Kasher 2004:580-581). ${ }^{40}$ There are three main characteristics for this pattern: (1) correspondence between the opening and closing parts of the homily; (2) in addition to the main quotation from the Old Testament, there is at least one subordinate quotation, also from the Old Testament; (3) Words from the text are paraphrased or quoted in the homily (Borgen 1965:47).

Thus, the prophecy of Isaiah 1:9 is given a positive spin to affirm that God's word has not failed as a remnant of Israel has been preserved. The remnant of Israel in Roman 9:28 is the seed in 9:29, thereby implying the believing Jews of whom Paul has already declared as the ones whom God has called in Roman 9:24. Therefore, the seed is those whom the Lord has graciously preserved according to his own purpose by calling them into a new community that includes Jews and Gentiles. Wright underscored this when he comments on how 'unwise it is to imagine that Abraham's true "seed" in 9:7 is simply a subset of ethnic Israel. In 4:16 it is already clearly a worldwide family' (Wright 1991:238). Thus, in light of Paul's grief in Roman 9:1-5, he finds comfort in God's word that does not fail. God is reserving for himself a seed that goes beyond the national boundaries of Israel. However, this begs the question: Does the broadening of the concept of seed imply that Gentile Christians assume an Israel or Israelite identity?

\section{Gentile others and Israel or Israelite identity}

Paul's mission to the Gentiles ( $\tau \grave{\alpha}$ č $\theta v \eta)^{41}$ required an attempt to redefine the boundaries between Jew/Israel and Gentiles. However, there are different perspectives among scholars regarding how Paul redefined the boundaries. There are four primary positions, which I will briefly highlight:

1. The church as a 'new Israel' (see Schreiner 1983:17-38; Waltke 1988:263-288; LaRondelle 1983): In this view, the believing Jews and Gentiles take over the title of 'Israel' and therefore are the 'new Israel'. The church is now the people of God taking over Israel's identity. Therefore, there is a sense in which there is continuity and discontinuity with the historic Israel or ethnic Israel. This view may also be classified under replacement theology or supersessionism. The church is, thus, not merely the 'new Israel' but is also conceived of as 'true Israel'.

\footnotetext{
38.Philo, All. ill:65-75a; ill:169-173; Sacr. 76-87.

39.On Exodus - Mekhilta de-R. Yishmael and Mekhilta de-R. Shimon ben Yohai; on Leviticus - Sifra, Numbers - Sifrei, Sifrei Zuta and Deuteronomoy - Sifrei, Midrash Tannaim.

40.For other examples from the New Testament see, Galatians 3:6-29; Roman 4:1-22; John 6:31-58.

41.The Greek term may be translated as 'nations' or 'other people'; furthermore, it is from the Greek term "ै $\theta$ voc that the term ethnic(ity) is derived. The term is in other instances used in contrast to the Jews or Israel in which case it may also be instances used in contrast to the Jews or Israel in which case it may also be
translated as non-Jews or non-Israelites (e.g. Mt 6:32; 10:18; Ac 11:1, 18; 14:5; translated $\mathrm{Rm}$ 3:39).
}

2. The church as a redefined Israel (Ladd 1964:206-214; Lincoln 1987:605-624; Ridderbos 1975): This view, while somewhat similar with the preceding view differs in that, the church is not viewed as a replacement of ethnic Israel; rather, it is the continuation of Israel that is redefined. Israel continues through the 'remnant', that is, the Jews who believe in Christ, furthermore it includes the believing Gentiles.

3. The distinction between Jews and Gentiles/Greeks is done away with (see Sanders 1983:178-179): In this view, the fact that the church is composed of both Jews and Greeks required the abolishing of these identities to form a synthesis, following Hegel's dialectic theory. In Baur's words, 'the distinction between Jews and Gentiles is cancelled in the unit of the new man, so Christianity stands above Gentilism and Judaism as the absolute religion' (Baur 2019). Thus, in Baur's view in the formation of the Christianity emerged a new super race, which was neither Jewish nor Gentile. A similar position was already advocated during the 4 th century AD by John Chrysostom, who argued for that the Jews and Gentiles became 'one new man' - blended together in Christ (see Rader 1978:32-35).

4. Jews and Gentiles are both included in the covenant. For the proponents of this view, the central concept is that of covenant. The covenant which was initially reserved for Israel is widened to include the Gentiles. However, the widening of the covenant in this regard does not amount to inclusion into Israel rather in Gentile believers standing alongside the Jewish believers. As Campbell (2008) argued:

Paul's thesis is that God's intention revealed in the Christ-event is to offer to two peoples an inclusive salvation that includes Jews as Jews and gentiles as gentiles, and that the grace of God is fully revealed when Israel and the nations share in the nurture of the one olive tree. (p. 127)

While Paul does not call the church 'Israel' in Roman 9 or the rest of the letter; there are instances, however, wherein Paul uses concepts pointing to Gentiles' 'inclusion in' or 'sharing in' what initially belonged exclusively to Israel: Firstly, there is progression of salvation, distress and glorification: first for the Jews and then for the Gentiles (Rm $1: 16 ; 2: 9,10)$. Therefore, there is a sense in which the Jews retain precedence over the Gentiles, yet not excluding the Gentiles. Secondly, the inclusion of the Gentiles into what initially belonged to Israel comes as a result of the hardening of Israel. Therefore, through the hardening, the Gentiles get an opportunity for inclusion: (1) Gentiles who were not God's people or beloved get an opportunity to be called God's people, his sons and his beloved (Rm 9:25-26); (2) the Gentiles are given an opportunity to be 'grafted in' where Israel's branches have been broken off ('E $\xi \varepsilon \kappa \lambda \alpha \dot{\sigma} \sigma \theta \eta \sigma \alpha \nu$

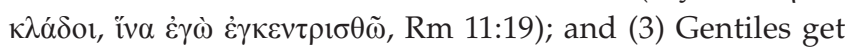

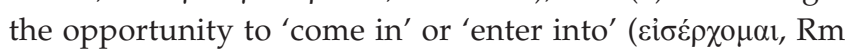
11:25). Thirdly, the Gentiles have a share in what initially belonged uniquely to the - a share in Jews' spiritual

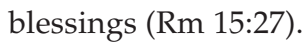


Scholars suggest that Paul was prompted to address the Jews-Gentiles dilemma because of the Gentile Christian assumption that they were capable of attaining salvation in Christ with or without Israel. As Käsemann (1980) framed it:

For Paul there can be no church of gentile Christians alone ... the concept of the people of God growing out of the root of Israel has, therefore, an indispensable function in Paul's ecclesiology, even though it is only one of its aspects and not even the centre. (p. 309)

In a similar vein, Campbell (2008) argued that the:

Christ-following gentiles cannot by right claim the inheritance of Israel in and by themselves, the covenant is not their covenant but the promises are mediated via Israel and shared through Christ and Israel. (p. 137)

Therefore, in this view, the Gentile believers were in the wrong and were thus being reprimanded for trying to force the Jewish believers to gentilise (Campbell 2008:113). However, it may also be that there was a dominant Jewish believing group in Rome, who may have demanded that Gentiles embrace Jewish identity and customs/practices. The priority of the Jews in relation to the Gentiles is maintained throughout the letter: firstly, it is the Jews who were prime, and then the Gentiles who were presented the opportunity of salvation; secondly, it was the Jews who were cut-off for the sake of Gentiles' salvation and thirdly, the Gentiles' salvation will also be for the benefit of the Jews. Thus, for Paul, the two had to accept and appreciate each other without seeking to exclude the other but honouring their ethnic peculiarities (Davies 1977:4-39, 23).

\section{Entering into the debate of Jews-Gentiles/ Israel-Gentiles? Do Gentiles have a say}

In addressing the Jews-Gentile/Israel-Gentiles debate, Paul does so from the Jewish perspective and developed his argument utilising Jewish Scriptures. The Pauline perspective should not be equated with the Gentiles or be viewed as representing the Gentiles' self-understanding. Paul equates himself with Israel:

I ask then: Did God reject his people? By no means! I am an Israelite myself, a descendant of Abraham, from the tribe of Benjamin. (Rm 11:1 NIV)

While Paul had noble intentions towards the Gentiles, the primary targets of his apostleship mandate to call them to faith. However, Paul's letter to those in Rome, who were predominantly Gentile, communicates with them, but does not speak on their behalf. Therefore, the Gentiles are voiceless in Paul's letter, and neither do we have at our disposal their response to Paul's idea of their inclusion or exclusion in Israel or Israel's blessings. While we may read between the lines the likely response of Paul's Gentile audience; it does not, however, have to stop us from responding to what comes to us as part of a book of faith, the Bible.

This is my point of view as a Gentile ("zovos) other:
Considering the terms Paul uses to refer to Gentiles in Romans - ${ }^{\prime} \theta v o s$ and "E $\mathrm{A} \lambda \eta \nu$, I am not a "E $\lambda \lambda \eta v$, that is, a Greek/ Hellene or Greek speaking, rather I am the other from other 'nations' ( $\chi \grave{\alpha} \check{\varepsilon} \theta v \eta)$. Therefore, unlike Paul, I am not a descendant of Abraham, nor am I an Israelite. I am Muvenda mubikwa na ive, ive la vhibva nne nda sala (a muvenda, the one cooked with stone, the stoned was cooked but I was not), a 'seed' of the Babirwa people whose lineages are found among the Vhavenda, Bapedi, Batswana and among the Shona in Zimbabwe. I chose to retain my identity, just as Paul chose to refer to himself as an Israelite, a descendant of Abraham and a Benjamite. Nor do I want to claim to be part of the lost tribes of Israel. However, there are those among our people, Vhalemba (Vhashavhi), who are known as the 'black Israelites or Jews of Southern Africa' who (believe that they) are Israel's descendants. Similarly, in Ethiopia, there is the presence of black Jews, whose presence goes as far back as the Second Temple period or earlier, and furthermore, those in Ethiopia hold on to a tradition which genealogically links their kingship line to king Solomon via the Queen of Sheba. I wonder what you would say to them: Would you consider them 'a remnant' of Israel too?

Paul, in his letter, asks the question: 'Is God the God of Jews only? Is he not the God of Gentiles too?' and he responded by saying: 'Yes, of Gentiles too' ( $\mathrm{Rm}$ 3:29). In answering in the affirmative, he also confirms what our African ancestors knew and believed. The colonialists attempted to erode this by projecting African people as people without religion or without God, thus, Africa came to be viewed as a dark continent full of heathens who needed to be converted. In the South African context, the Biblical text was not simply utilised as a colonising instrument. It was also employed to justify exclusionary colonial-apartheid policies which rendered the indigenous black people as racially inferior and emphasised the separateness of people based on skin pigmentations, cultures and languages (see Dutch Reformed Church 1976).

Through European colonialism and Christianisation of Africa, some of our African people's identities were forever altered through name changing as they were given so-called 'Christian names', which are Europeanised Jewish names from the Bible. This tradition of giving the so-called 'Christian names' or broadly European names continues thereby further diluting and distancing Africans from their own identities. This should make us wonder if the Christianity strand imported to Africa by the Europeans, which Africans have come to embrace, is not a form of Western colonialism that not only suppresses African identities but imposes a new ideology of regarding our own African origins, traditions and cultures as irrelevant (see Sanni 2016:1-13, 7).

\section{Conclusion}

The discussion about who qualifies to be included in 'Israel' or identified as 'Israel' or rather to stand alongside 'Israel' with the scope of salvation as presented in the Scriptures 
both Old and New Testament present Jewish perspectives without hearing the voice of the others, the Gentiles. The received text, as we have it, is a Jewish text, does not represent the Gentile perspective. It may well be, as some claim, that Paul was defending his own people, Israel, against the Gentile believers' condescending view that they could claim salvation without Israel's mediation. Be that as it may, in the case of Africa, during the colonial-apartheid era, biblical texts were deployed by and large to uproot us from our own identities by plunging us into inferiority and enslavement. The same biblical texts were appropriated afresh and given new life to affirm our humanity and dignity. Unless the Lord of hosts (African ancestors) had left us a seed during European colonialism, Africa would have been left desolate through slavery, and we would have been completely dispossessed of our land.

Paul's choice and use of Isaiah 1:9 was influenced by his reading of the Scriptures in their Greek translation (LXX). This text which in its original context was used negatively to show God's pending judgment upon Israel's survivors was used by Paul to generate a positive impact as it came to serve as affirmation of God's faithfulness. As Watson argued, for Paul, the argumentation through Scripture is not merely to instruct but also to generate hope, 'a scripturally based hope for the future transformation begins to dawn' (Watson 2007:333).

The transformation that African believers should strive for is to embrace their Africanness with the blessings that come with being in Christ; rather than to see their Africanness as something to be replaced or left behind.

\section{Acknowledgements}

\section{Competing interests}

The author declares that he has no financial or personal relationships that may have inappropriately influenced him in writing this article.

\section{Author's contributions}

H.R. is the sole author of this article.

\section{Ethical considerations}

This article followed all ethical standards for research without direct contact with human or animal subjects.

\section{Funding information}

This research received no specific grant from any funding agency in the public, commercial or not-for-profit sectors.

\section{Data availability}

Data sharing is not applicable to this article as no new data were created or analysed in this study.

\section{Disclaimer}

The views and opinions expressed in this article are those of the author and do not necessarily reflect the official policy or position of any affiliated agency of the author.

\section{References}

Alon, G., 1977, 'The Levitical uncleanness of Gentiles', in Jews, Judaism and the classical world, pp. 146-189, transl. I. Abrahams, Magnes Press, Jerusalem.

Bakhtin, M., 1981, 'Discourse in the novel', in M. Holquist (ed.), Dialogic imagination: Four essays by Mikhail M. Bakhtin, pp. 259-422, transl. C. Emerson and M. Holquist, University of Texas Press, Austin, TX.

Barram, M., 2007, 'The Bible, mission, and social location: Toward a missional hermeneutic', Interpretation 61(4), 42-58. https://doi.org/10.1177/002096430006100106

Baur, F.C., 2019, Christianity and the Christian church of the first three centuries, ed. Peter C. Hodgson, transl. Robert F. Brown and Peter C. Hodgson, Cascade, Eugene, OR.

Beker, J.C., 1993, 'Echoes and intertextuality: On the role of scripture in Paul's theology', in C.A. Evans \& J.A. Sanders (eds.), Paul and scriptures of Israel, Journal for the Study of the Old Testament, Sheffield.

Bird, M.F., 2010, Crossing over sea and land: Jewish missionary activity in the second temple period, Hendrickson, Peabody, MA.

Borgen, P., 1965, Bread from heaven, Supplements to Novum Testamentum 10, Brill, Leiden.

Bruce, F.F., 1983, 'Biblical exposition at Qumran', in R.T. France \& D. Wenham (eds.) Gospel perspectives: Studies in Midrash and historiography, pp. 77-98, vol. 3, JSOT, Sheffield.

Büyüm, A.M., Kenney, C., Koris, A., Mkumba, L. \& Raveendran, Y., 2020, 'Decolonising global health: If not now, when?', BMJ Global Health 5(8), 1-4. https://doi. org/10.1136/bmjgh-2020-003394

Campbell, W.S., 2008, Paul and the creation of Christian identity, T\&T Clark, London.

Cohen, S.J.D., 1989, 'Crossing the boundary and becoming a Jew', The Harvard Theological Review 82(1), 13-33. https://doi.org/10.1017/S001781600001600X

Conczorowski, B. \& Frevel, C., 2011, 'All the same as Ezra? Conceptual differences between the texts on intermarriage in genesis, Deuteronomy 7 and Ezra', in C. Frevel (ed.) Mixed marriages, intermarriage and group identity in the Second Temple period, pp. 81-108, T\&T Clark International, London.

Cosgrove, C.H., 1996, 'Rhetorical suspense in Romans 9:11: A study in polyvalence and hermeneutical election', Journal of Biblical Literature 115(2), 271-287. https:// doi.org/10.2307/3266856

Cranfield, C.E.B., 1975, Epistle to the Romans, II. International Critical Commentary, T \& T Clark, Edinburgh.

Davies, D.W., 1977, 'Paul and the people of Israel', New Testament Studies 24(3), 4-39. https://doi.org/10.1017/S002868850000374X

De Villiers, G., 2019, 'The "foreigner in our midst" and the Hebrew Bible', HTS Teologiese Studies/Theological Studies 75(3), a5108. https://doi.org/10.4102/hts. v75i3.5108

Dodd, C.H., 1932, The epistle of Paul to the Romans, Harper and Brothers, New York, NY.

Dutch Reformed Church, 1976, Human relations and South African scene in the light of scripture, Dutch Reformed Church Publishers, Cape Town.

Ellis, E.E., 1957, Paul's use of the Old Testament, Oliver and Boyd, Edinburgh.

Ellis, E.E., 1978, Prophecy and hermeneutic in early Christianity, J. C. B. Mohr, Tubingen

Enns, P., 2005, Inspiration and incarnation: Evangelicals and the problem of the Old Testament, Baker Academic, Grand Rapids, MI.

Epstein, L., 1942, Marriage laws in the Bible and Talmud, Harvard University Press, Cambridge.

Ginzberg, L., 1913, The legends of the Jews: From creation to Jacob, vol. 1., transl. Henrietta Szold, The Jewish Publication Society of America, Philadelphia, PA.

Harnack, A., 1928, 'Das alte Testament in den Paulinschen Briefen und in den paulinischen Gemeinden', in Sitzungsberichte der Preussischen Akademie der Wissenschaften Philosopisch-Historische Klasse, pp. 124-141, Akademie der Wissenschaften, Berlin

Hayes, C.E., 2002, Gentile impurities and Jewish identities: Intermarriage and conversion from the Bible to the Talmud, Oxford University Press, Oxford.

Hays, R.B., 1989, Echoes of scripture in the letters of Paul, Yale University Press, New Haven, CT.

Heil, J.P., 2002, 'From remnant to seed of hope for Israel: Romans 9:27-29', Catholic Biblical Quarterly 64(4), 703-720.

Käsemann, E., 1980, Commentary on Romans, transl. \& ed. Geoffrey W. Bromiley, Eerdmans, Grand Rapids, MI.

Kasher, R., 2004, 'The interpretation of scripture in Rabbinic literature', in M.J. Mulder \& H. Sysling (eds.), Mikra: Text, translation, reading \& interpretation of the Hebrew Bible in Ancient Judaism \& early Christianity, pp. 547-594, Hendrickson Publishers, Peabody, MA.

Kugel, J.L., 1990, In Potiphar's house: The interpretive life of biblical texts, Harper, San Francisco, CA. 
Ladd, G.E., 1964, 'Israel and the Church', The Evangelical Quarterly 36(4), 206-214.

LaRondelle, H.K., 1983, The Israel of God in Prophecy: Principles of prophetic interpretation, Andrews University Press, Berrien Springs, MI.

Leland, R., Wilhoit, J.C. \& Longman, III. T. (eds.), 1998, Dictionary of biblical imagery, InterVarsity Press, Westmont, IL.

Lentz, Jr., J.C., 1993, Luke's portrait of Paul, SNTSMS 77, Cambridge University Press, Cambridge.

Levenson, J.D., 1992, 'Zion', in D.N. Freedman (ed.), The Anchor Bible Dictionary, pp. 1098-1102, vol. VI., Doubleday, New York, NY.

Lincoln, A.T., 1987, 'The church and Israel in Ephesians 2', The Catholic Biblical Quarterly 49(4), 605-624.

Longenecker, B.W., 1989, 'Different answers to different issues: Israel, the Gentiles and Salvation history in Romans 9-11', Journal for the Study of the New Testament 36, 95-123. https://doi.org/10.1177/0142064X8901103606

Longenecker, R.N., 1997, 'Prolegomena to Paul's use of scripture in Romans', Bulletin for Biblical Research 7, 1-24.

Longenecker, R.N., 1999, Biblical exegesis in the Apostolic period, 2nd edn., Eerdmans, Grand Rapids, MI.

Mahmud, T., 1999, 'Colonialism and modern constructions of race: A preliminary inquiry', University of Miami Law Review 53(4), 1219-1246.

Mekhilta, 1976, 'Tractacte Pisha chapter I', in Mekhilta Rabbi Ishmael I, pp. 1-2, transl. J. Lauterbach, The Jewish Society of America, Philadelphia, PA.

Mihaly, E., 1964, 'A rabbinic defense of the election of Israel: An analysis of Sifre Deuteronomy 32:9, Pisqa 312', Hebrew Union College Annual 35(1), 103-143.

Neusner, J., 1989, Writing with scripture: The authority and uses of the Hebrew Bible in the Torah of formative Judaism, Fortress Press, Minneapolis, MN.

Neusner, J., 1995, Rabbinic Judaism: Structure and system, Fortress Press, Minneapolis, $\mathrm{MN}$.

Nolan, G., 1982, 'The role of the Kenites in Israel's History', DTh dissertstion, New Orleans Baptist Theological Seminary, New Orlean, LA.

Olyan, S., 2000, Rites and rank: Hierarchy in biblical representation of Cult, Princeton University Press, Princeton, NJ.

Pakkala, J., 2011, 'Intermarriage and group identity in the Ezra tradition (Ezra 7-10 and Nehmiah 8)', in C. Frevel (ed.), Mixed marriages, intermarriage and group identity in the second temple period, pp. 78-88, T\&T Clark International, London.

Palmer, C., 2018, Converts in the dead sea scrolls, Studies on the Tests of the Desert of Judah, vol. 126., Breill, Leiden.

Philo, O.A. \& Yonge, C.D., [c1993] 1996, The works of Philo: Complete and unabridged, Hendrickson, Peabody, MA.

Ramantswana, H., 2016, 'Decolonising biblical hermeneutics in the (South) African context', Acta Theologica Supplement 24, 178-203.

Rader, W., 1978, The church and racial hostility: A history of interpretation of Ephesians 2:11-22, Mohr Siebeck, Tübingen.
Ridderbos, H., 1975, Paul: An outline of his theology, transl. John R. De Witt, Eerdmans, Grand Rapids, MI.

Sanders, E.P., 1983, Paul, the law, and the Jewish people, Fortress Press, Philadelphia,

Sanders, E.P., 2008, 'Common Judaism explored', in W.O. McCready \& A. Reinhartz (eds.), Common Judaism: Explorations in second-temple Judaism, pp. 11-23, 228-232, Fortress Press, Minneapolis, MN.

Sanni, J.S., 2016, 'Religion: A new struggle for African identity', Phronimon 17(2), 1-13, 7. https://doi.org/10.17159/2413-3086/2016/120

Schreiner, T.R., 1998, Romans, Baker Exegetical Commentary on the New Testament, Baker Academic, Grand Rapids, MI.

Schreiner, T.R., 1983, 'The church as the New Israel and the future of ethnic Israel in Paul', Studia Biblica et Theologica 13(1), 17-38.

Scroggs, R., 1976, 'Paul as Rhetorician: Two homilies in Romans 1-11', in R. HamertonKelly \& R. Scroggs (eds.), Jews, Greeks and Christians: Religious culture in late antiquity: Essays in honor of William David Davies, pp. 271-298, Brill, Leiden.

Segovia, F.F., 1995, 'Culture studies and contemporary biblical criticism', in F.F. Segovia \& M.A. Tolbert (eds.), Reading from this place, Volume 2: Social location and biblical interpretation in global perspective, pp. 1-17, Fortress Press, Minneapolis, MN.

Stegemann, W., 1987, 'War der Apostel Paulus ein römischer Bürger?', Zeitschrift für die Neutestamentliche Wissenschaft und die Kunde der Älteren Kirche 78(3), 200-229.

Stegner, W.R., 1984, 'Romans 9:6-29 - A Midrash', Journal for the Study of the New Testament 22(1), 37-52. https://doi.org/10.1177/0142064X8400702203

Southwood, K.E., 2014, 'Will Naomi's nation be Ruth's nation?: Ethnic translation as a metaphor for Ruth's assimilation within Judah', Humanities 3, 102-131. https:// doi.org/10.3390/h3020102

Sweeney, M.A., 1996, Isaiah 1-39 with an introduction to prophetic literature, FOTL XVI, Eerdmans Publishing, Grand Rapids, MI.

Wakefield, A.H., 2003, 'Romans 9-11: The sovereignty of God and the status of Israel', Review \& Expositor 100(1), 65-80. https://doi.org/10.1177/ 003463730310000105

Wassen, C., 2016, 'The Jewishness of Jesus and ritual purity', Scripta Institut Donneriani Aboensis, 27, 11-36. https://doi.org/10.30674/scripta.66567

Waltke, B.K., 1988, 'Kingdom promises as spiritual', in J.S. Feinberg (ed.), Continuity and discontinuity: Perspectives on the relationship between the Old and New Testament, essays in honor of S. Lewis Johnson, Jr., pp. 263-288, Crossway, Westchester.

Watson, F., 2007, Paul, Judaism and the Gentiles: Beyond the new perspective, rev. \& expanded edn., Eerdmans, Grand Rapids, MI.

Watts, J.W., 2005, 'Ritual legimacy and scriptural authority', Journal of Biblical Literature 124(3), 401-417. https://doi.org/10.2307/30041032

Wright, N.T., 1991, The climax of the covenant: Christ and the Law in Pauline theology, Fortress Press, Minneapolis, MN 